\title{
ENDODONTIC TREATMENT AND PREMATURE TOOTH LOSS IN PRIMARY DENTITION. REASONS AND DISTRIBUTION
}

\author{
Milena Georgieva-Dimitrova, Radosveta Andreeva \\ Department of Pediatric Dentistry, Faculty of Dental Medicine, \\ Medical University of Varna
}

\begin{abstract}
INTRODUCTION: Primary dentition has its own role in every individual's life affecting the general health by ensuring the integrity of the permanent dentition. It has significant impact on the position, teeth and jaw relations as well as the vocal and eating functions. Thus, preventing its health is very important for the children.

AIM: The aim of this article is to investigate the relative share of the primary teeth with $\mathbf{d} 4$ carious lesions and traumatic injuries indicated for endodontic treatment, reasons for retreatment, premature loss, and extraction of primary teeth.

MATERIALS AND METHODS: A retrospective descriptive study was conducted by examining 1159 children 3 to 12 years old, from Varna in the University Medical Dental Center - Varna, where a $\mathbf{d} 4 \mathrm{mf} / \mathrm{d} 4 \mathrm{mf}(\mathrm{T}+\mathrm{t})$ was assessed in the period 2016-2019. Teeth indicated for endodontic treatment and endodontic retreatment were investigated. Teeth for extraction due to orthodontic issues and teeth with normal exfoliation were not taken into account.

RESULTS: It was established that $37.8 \%$ of 1159 children were with a diagnosed $\mathbf{d} 4$ carious lesions. The main reason for endodontic treatment of primary teeth in $62 \%$ of the children diagnosed with complicated caries was irreversible pulpitis. A total of $34 \%$ of the children were diagnosed with periodontitis. Traumatic injuries with pulp necrosis represented $14 \%$ of the complications. The main reasons for premature extraction of primary teeth were carious process complications (36\%) and unsuccessful previous endodontic treatment (49\%).
\end{abstract}

CONCLUSION: Although people use their primary dentition for just $6 \%$ of their lifetime, it has crucial impact on the health, orthognathic relations, and positions of permanent teeth.

Keywords: endodontic treatment, primary dentition, reasons for premature loss of primary teeth

\footnotetext{
Address for correspondence:

Milena Georgieva-Dimitrova

Faculty of Dental Medicine

Medical University of Varna

84 Tzar Osvoboditel Blvd

9002 Varna

e-mail:dr.milena.georgieva89@gmail.com
}

Received: June 6, 2019

Accepted: September 23, 2019 
Milena Georgieva-Dimitrova, Radosveta Andreeva

\section{INTRODUCTION}

Due to high frequency of caries in childhood age it is important for the dentists to be acquainted with the restoration and preventive techniques on primary dentition. It is very important for the children's oral health and development to preserve the integrity of the teeth and the dental arch (1). Maximum efforts should be invested in preserving primary teeth until their physiological exfoliation $(2,3)$. The premature loss of a primary tooth may cause loss of space, delayed or ectopic eruption of the permanent tooth (4). The endodontic treatment of primary teeth keeps them in the dental arch in cases with hypodontia, prevents bad habits like infant swallowing, preserves the normal masticatory function and the aesthetics (1). The primary teeth have important significance for keeping the space for their successors, the outlook of the patient, and the speech development (2). There are techniques for preserving the primary teeth involved in pulp inflammation and abscess (1). The success and high quality of the endodontic treatment depends on the sealing and preventing of microleakage as well as on the integrity of the restoration (5). The treatment is considered to be successful when after a certain period of time the radiograph shows no pathologic lesions in the underlying bone, the tooth carried out its function without any symptoms and discomfort, until the eruption of the permanent successor, with normal physiological resorption and no pathologic mobility (6). After the treatment of pulpitis and periodontitis of primary teeth it is necessary for the restoration to fulfill several criteria - to be durable and to provide protection for the weakened hard tooth tissues, in other words not to have to be changed with new one in time (1). Changing defective restorations is the most common manipulation in the pediatric dentistry (7). The secondary caries and the fractures of the filling are the main reasons for the failure of the restorations in the distal area of the dentition (8). The repetitive change of defective fillings leads to additional loss of hard tooth tissues $(9,10)$. This is crucial for the permanent teeth due to the thinner enamel and dentin tissues which may increase the risk of complications and premature loss of primary teeth (11). Everyday practice shows that teeth with endodontic treatment and multisurface restorations experience the highest failure rates (12).

\section{AIM}

The aim of this article is to investigate the relative share of the primary teeth with $\mathrm{d} 4$ carious lesions and traumatic injuries indicated for endodontic treatment, reasons for retreatment, premature loss, and extraction of primary teeth.

\section{MATERIALS AND METHODS}

A retrospective descriptive study was conducted by examining of 1159 children with primary and mixed dentition in the University Medical Dental Center - Varna in the period 2016-2019. The sample included children 3-12 years of age who visited the dental office either for treatment or prophylactic check-up. The number and the condition of already treated teeth and teeth indicated for endodontic treatment due to complication of the caries process and failed filling materials was assessed. In total, 230 primary teeth with irreversible pulpitis, 122 teeth with chronic periodontitis, and 308 extracted teeth were registered and assessed. The extracted teeth for orthodontic purposes and due to normal exfoliation were not object of the current study. The $\mathrm{dmft} / \mathrm{dmft}(\mathrm{T}+\mathrm{t})$ index was estimated with diagnostic criteria $\mathrm{d} 4$ ( $\mathrm{d} 4$ stands for complicated carious lesions with pulp and periodontium involved in an inflammation process), recurrent infection and reasons for early extraction of primary teeth, failed restorations of endodontically treated teeth. Descriptive statistical analysis was carried out with estimation of the percentages of children and/or teeth with specific diseases/complications and respective 95\% confidence intervals.

\section{RESULTS}

Out of all 1159 examined and treated 3- to 12-year-old children from both genders, 37.8\% (95\% CI: $35 \%-40.7 \%)$ were diagnosed with d4 carious lesions. The main reason for endodontic treatment of primary teeth in $62 \%$ (95\%CI: $56.4 \%$ - $67.3 \%)$ of the 438 children diagnosed with complicated caries was irreversible pulpitis. In 34\% (CI 95\%: 26.7\%-40.8\%) of the 438 children diagnosed with $\mathrm{d} 4$ caries lesions a diffuse inflammation in the underlaying bone was registered. The ratio of the cases with pulpitis to periodontitis was 2:1. Traumatic injuries with pulp necrosis represented 14\% (CI 95\%: 9.17\%-18.8\%) of all 
complications, which required endodontic treatment of primary teeth (Fig. 1).

The main causes for endodontic retreatment of primary teeth are shown on Fig. 2. In total, 71 out

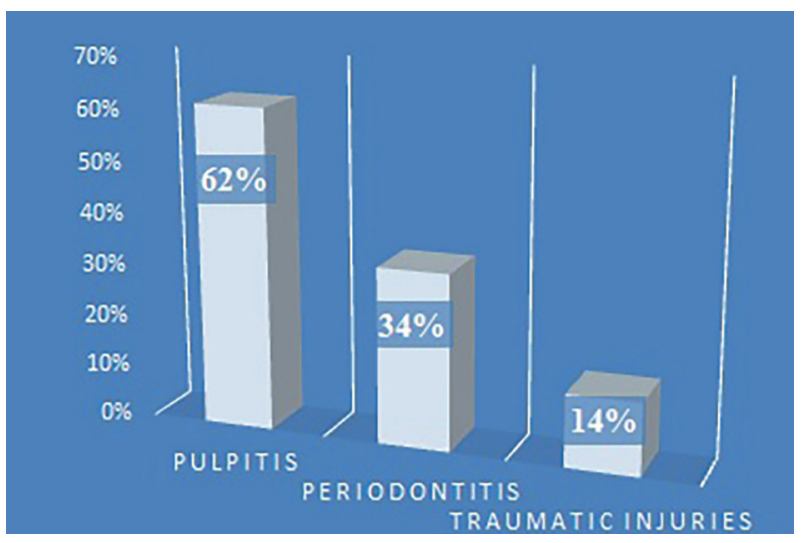

Fig. 1. Reasons for endodontic treatment in primary teeth (\%)

of 230 teeth with a diagnosed irreversible pulpitis required retreatment because of recurrent infection and its further progression to periodontitis. This was observed in 31\% (CI 95\%: 30.67\%-32.8\%) of the 230 teeth with primary endodontic treatment. In $69 \%$ (CI 95\%: 68.5\%-70.7\%) of the 352 teeth with previous endodontic treatment the main reason for the retreatment was a defective filling and the microleakage in the dental root canal system of the primary tooth. This may cause reinfection from the oral environment.

The premature extraction of teeth in childhood age, before their normal exfoliation, was due to com-

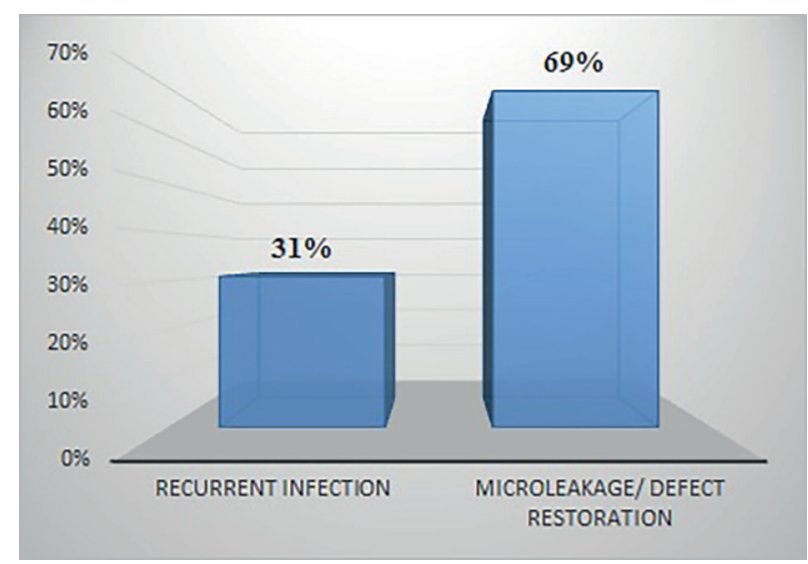

Fig. 2. Reasons for endodontic retreatment in primary teeth $(\%)$ plications caused by a carious process in 36\% (CI 95\%: $27.3 \%-44.77 \%$ ) of 308 extracted teeth and by unsuccessful previous endodontic treatment - 49\% (CI 95\%: 40.6\%-57.3\%) of the cases with premature extraction in our study, both being a huge problem in the pediatric dentistry and orthodontics (Fig. 3). Significantly less common cause for premature extraction were the non-restorable crown fractures - 11\% (CI 95\%: 10.8\%-11.2\%) of all 308 extracted teeth, including those in devitalized teeth, and general systemic diseases - 4\% (CI 95\%: 2.6\%-5.16\%) which can lead to early loss of primary teeth in childhood age. It was established the main reason for early loss of primary teeth in our study remains the caries process and its complications. The high quality of the treatment of devitalized primary teeth and the longevity of the restorations greatly decreases the risk of early extraction.

\section{DISCUSSION}

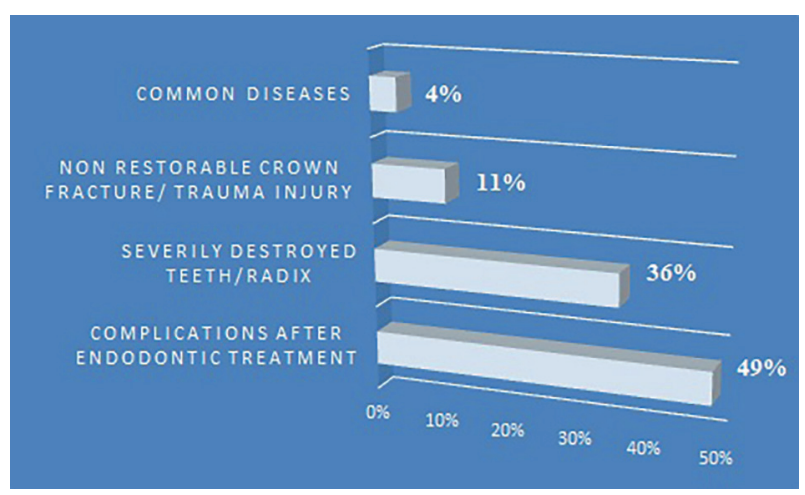

Fig. 3. Percentage distribution of the reasons for early extraction of primary teeth

Many studies support the idea that the most common cause for toothache and endodontic treatment is the complicated caries and the inflammation of the pulp (75-85\% of the cases) (13). The caries prevalence reaches up to $93 \%$ among children in the population and $30 \%$ to $43 \%$ of the caries cases are associated with complications in primary molars (14). It is established that one of every 4 children experiences the consequences of the untreated caries pulpitis or periodontitis, which leads to endodontic treatment or extraction of the tooth. In $41 \%$ of the children with untreated caries a progression of the process is observed (15). In children in school age the 
inflammation of the pulp represents half of the complications of the untreated caries (16). The mandibular molars are more often affected by severe (d4) carious lesions than the maxillary ones (17). Different studies report that neglecting the dental treatment in school age leads to pulp inflammation and odontogenic infections (18). This may be due to lack of information about oral health, neglect by the parents, lack of oral care admission (15). Odontogenic pain is with relatively high distribution among children in school age and it is a reason for decreased quality of life, having a negative impact on eating, social integration, absence from school, sleep and physical activity (19-25).

There are several causes, which may lead to unfavorable outcome of the endodontic treatment of primary teeth. The different morphology in the root canal system in primary teeth may lead to difficulties in the mechanical treatment and disinfection. After an unsuccessful endodontic treatment of primary teeth, there are two possible choices for treatment - either extraction or retreatment. The success rates 1 year after endodontic treatment are $65.74 \%$. The share of failures represents $34.2 \%$ of the cases as more often molars are treated compared to the frontal teeth. Out of all treated teeth with pulpitis $29.8 \%$ are liable to retreatment (26).

Many studies have confirmed that the quality of the endodontic treatment depends on the restoration of the treated tooth (27). The resin composite and preformed metal crowns (PMCs) have shown high success rates in endodontically treated teeth in vivo and in vitro. Composite restorations are with high integrity and have shown really high efficiency in very deep carious lesions around $6 \mathrm{~mm}$. PMCs show good results regarding micro leakage in the cervical area $(28,29)$. The choice of restoration material is an important factor for the success of certain endodontic treatment. PMCs are known to be the best restoration material after pulpal therapy (30).

A study by Guelmann et al. (31) reported that the best marginal adaptation is provided by composite materials over glass ionomer cement (GIC) and intermediate restorative material (IRM). PMCs cemented with GIC showed that tightness is not that good. Composites and compomers cannot prevent the microleakage but they have better adaptation compared with conventional GICs (32).

In a research in Northeast Bulgaria in 2016, Andreeva (33) reported that the main reason for premature loss of primary teeth is complicated carious lesions $-94 \%$ of the cases. Trauma injuries represented only $5.7 \%$ of the cases with early loss of primary teeth, with the risk increasing with age (34).

\section{CONCLUSION}

The health of primary dentition has a very important role in the everyday life of children, their social contacts and self-confidence. Although people use it just for $6 \%$ of their lifetime, it has a crucial impact on the health, orthognathic relations, and positions of permanent teeth. One of the main reasons for premature loss of primary teeth is the most common chronic oral disease in the world - caries and its complications.

\section{REFERENCES}

1. Duggal MS, Curzon MEJ, Fayle SA, Pollard MA, Robertson AJ. Restorative techniques in paediatric dentistry. 2nd ed. London: Martin Dunitz; 2002.

2. Srivastava VK. Modern pediatric dentistry. 1st ed. Jaypee Brothers Medical Publishers (P) Ltd.; 2011.

3. Togoo RA, Nasin V, Zakirulla M, Yaseen S. Knowledge and practice of pulp therapy in deciduous teeth among general dental practitioners in Saudi Arabia. Ann Med Health Sci Res. 2012;2(2):119-23. doi: 10.4103/2141-9248.105657.

4. Cameron A, Widmer R. Handbook of pediatric dentistry. Germany: Mosby; 2013. p. 93-102.

5. Ray HA, Trope M. Periapical status of endodontically treated teeth in relation to the technical quality of the root filling and the coronal restoration. Int Endod J. 1995; 28(10:12-8. doi: 10.1111/j.13652591.1995.tb00150.x.

6. Dummett Jr CO, Kope HM. Pediatricendodontics. In: Ingle J, editor. Endodontics. Philadelphia: Lea and Febiger; 2002. p.861-902.

7. Hilgert LA, Frencken JE, de Amorim RG, Mulder J, Leal SC. A study on the survival of primary molars with intact and with defective restorations. Int J Paediatr Dent. 2016; 26(5):383-90. doi: 10.1111/ ipd.12215.

8. Demarco FF, Corrêa MB, Cenci MS, Moraes RRON. Longevity of posterior composite restora- 
tions: not only a matter of materials. Dent Mater. 2012; 28(1):87-101. doi: 10.1016/j.dental.2011.09.003.

9. Adegbembo AO, Frcd C, Watson PA. Removal, replacement and placement of amalgam restorations by Ontario dentists in 2002. J Can Dent Assoc. 2005;71(8):565.

10. Elderton RJ. Clinical studies concerning re-restoration of teeth. Adv Dent Res. 1990;4:4-9. doi: 10.1177/08959374900040010701.

11. Lenzi TL, Marquezan M, Bonini GC, Camargo LB, Raggio DP. Repairing ditched amalgam restorations is less time and tooth structure-consuming than replacement. Eur Arch Paediatr Dent. 2013;14(5):345-9. doi: 10.1007/s40368-013-0091-y.

12. de Ávila NM, Bottezini PA, Nicoloso GF, de Araujo FB, Ardenghi TM, Lenzi TL, et al. Prevalence of defective restorations and factors associated with reintervention in primary teeth: A retrospective university-based study. J Paediatr Dent. 2019; 29(5):566-72. doi: 10.1111/ipd.12493.

13. Figueiredo MJ, de Amorim RG, Leal SC, Mulder J, Frencken JE. Prevalence and severity of clinical consequences of untreated dentine carious lesions in children from a deprived area of Brazil. Caries Res. 2011;45(5):435-42. doi: 10.1159/000330531.

14. Ramazani N, Rezaei S. Evaluation of the prevalence of clinical consequences of untreated dental caries using PUFA/pufa index in a group of Iranian children, Iran J Pediatr. 2017; 27(1):e5016. doi: 10.5812/ ijp.5016

15. Monse B, Heinrich-Weltzien R, Benzian H, Holmgren C, van Palenstein Helderman W. PUFA - an index of clinical consequences of untreated dental caries. Community Dent Oral Epidemiol. 2010;38(1):77-82. doi: 10.1111/j.1600-0528.2009.00514.x.

16. Bonanato K, Pordeus IA, Moura-Leite FR, RamosJorge ML, Vale MP, Paiva SM. Oral disease and social class in a random sample of five-year-old preschool children in a Brazilian city. Oral Health Prev Dent. 2010;8(2):125-32.

17. Moskovitz M, Sammara E, Holan G. Success rate of root canal treatment in primary molars. J Dent. 2005; 33(1):41-7. doi: 10.1016/j.jdent.2004.07.009.

18. Singhal DK, Singla N. Severity and clinical consequences of untreated dental caries using PUFA index among schoolchildren in Udupi Taluk, India. J Orofac Sci. 2018;10(1):19-23. doi: 10.4103/jofs. jofs_62_17.
19. Boeira GF, Correa MB, Peres KG, Peres MA, Santos IS, Matijasevich A, et al. Caries is the main cause for dental pain in childhood: findings from a birth cohort. Caries Res. 2012;46(5):488-95. doi: $10.1159 / 000339491$.

20. Edelstein B, Vargas CM, Candelaria D, Vemuri $M$. Experience and policy implications of children presenting with dental emergencies to US pediatric dentistry training programs. Pediatr Dent. 2006;28(5):431-7.

21. Feitosa S, Colares V, Pinkham J. The psychosocial effects of severe caries in 4-year-old children in Recife, Pernambuco, Brazil. Cad Saude Publica. 2005;21(5):1550-6. doi: 10.1590/ s0102-311x2005000500028.

22. Gherunpong S, Tsakos G, Sheiham A. The prevalence and severity of oral impacts on daily performances in Thai primary school children. Health Qual Life Outcomes. 2004;2:57. doi: 10.1186/1477-7525-2-57.

23. Guskuma RC, Lages VA, Hafner MB, RandoMeirelles MPM, Cypriano S, Sousa MLR, Batista MJ. Fatores associados à prevalência e intensidade de odontalgia em crianças de municípios da região de Campinas, SP. Rev Paul Pediatr 2017;35(3):1-9. doi: 10.1590/1984-0462/;2017;35;3;00001.

24. Peretz B, Sarnat H. Relations between dental and somatic pain in children. Int J Paediatr Dent. 2010;20(3):201-6. doi: 10.1111/j.1365-263X.2010.01041.x.

25. Souza JGS, Martins AM. Dental pain and associated factors in Brazilian preschoolers. Rev Paul Pediatr. 2016;34(3):336-42. doi: 10.1016/j. rpped.2015.12.007.

26. da Silva BS, Nicoloso GF, Ruiz LF, de Melo TAF, Casagrande L. Does endodontic re-treatment in primary teeth increase the functional tooth retention? A clinical, retrospective, university-based study. Pesqui Bras Odontopediatria Clin Integr. 2019;19(1):e3902. doi:10.4034/pboci.2019.191.10.

27. Bücher K, Metz I, Pitchika V, Hickel R, Kühnisch J. Survival characteristics of composite restorations in primary teeth. Clin Oral Investig. 2015;19(7):1653-62. doi: 10.1007/s00784-014-1389-9.

28. Seraj B, Shahrabi M, Motahari P, Ahmadi R, Ghadimi S, Mosharafian S, et al. Microleakage of stainless steel crowns placed on intact and extensively destroyed primary first molars: an in vitro study. Pediatr Dent. 2011;33(7):525-8. 
29. Zulfikaroglu, Burcu Togay; Atac, Atila Stephan; Cehreli, Zafer C. Clinical performance of class II adhesive restorations in pulpectomized primary molars: 12-month results. J Dent Child (Chic). 2008;75(1):33-43.

30. Guelmann M, Fair J, Turner C, Courts FJ. The success of emergency pulpotomies in primary molars. Pediatr Dent. 2002;24(3):217-20.

31. Guelmann M, Bookmyer KL, Villalta P, GarcíaGodoy F. Microleakage of restorative techniques for pulpotomized primary molars. J Dent Child (Chic). 2004;71(3):209-11.

32. Xie H, Zhang F, Wu Y, Chen C, Liu W. Dentine bond strength and microleakage of flowable composite, compomer and glass ionomer cement. Aust Dent J. 2008;53(4):325-31. doi: 10.1111/j.1834-7819.2008.00074.x.
33. Andreeva R. Prezhdevremenna zaguba na vremenni zabi pri detsa sas smeseno sazabie. Neobhodimost ot mestopaziteli, Disertatsiya, Varna, 2016. (in Bulgarian).

34. Cavalcanti AL, Bezerra PK, Alencar CR, Moura C. Traumatic anterior dental injuries in 7- to 12-year-old Brazilian children. Dent Traumatol. 2009;25(2):198-202. doi: 10.1111/j.1600-9657.2008.00746.x. 